\title{
On the Role of Dilute Solute Additions on Growth Restriction in Binary Copper Alloys
}

\author{
M. J. Balart ${ }^{1}$. F. Gao ${ }^{1}$ J. B. Patel ${ }^{1}$. F. Miani ${ }^{2}$
}

Received: 6 July 2020 / Revised: 27 September 2020 / Accepted: 14 October 2020 / Published online: 6 November 2020

(C) The Author(s) 2020

\begin{abstract}
The effect of dilute solute additions on growth restriction in binary $\mathrm{Cu}$ alloys has been assessed at different degrees of superheat. Columnar grain length values from Northcott's work (Northcott in J Inst Metals 62:101-136, 1938) for binary $\mathrm{Cu}$ alloys were plotted against the corresponding undercooling parameter $(\mathrm{P})$, the reciprocal of the conventional $\left(\mathrm{Q}_{\text {conv. }}\right)$ and true $\left(\mathrm{Q}_{\text {true }}\right)$ growth restriction factor (Schmid-Fetzer and Kozlov in Acta Mater 59(15):6133-6144, 2011) values. It was found that there was no correlation between the columnar grain length values and $\mathrm{P}, 1 / \mathrm{Q}_{\text {conv. }}$ and $1 / \mathrm{Q}_{\text {true }}$ values for different solutes and cast at the same degree of superheat. Unlike $\mathrm{P}, \mathrm{Q}_{\text {conv. }}$, and $\mathrm{Q}_{\text {true }}$ values, the heuristic growth restriction parameter ( $\beta$ ) (Fan et al. in Acta Mater 152, 248-257, 2018) modeling framework in conjunction with the critical solute content $\left(C^{*}\right)$ for growth restriction fitted well to binary $\mathrm{Cu}$ alloys.
\end{abstract}

Keywords Grain size - Supercooling parameter - Growth restriction factor - Growth restriction parameter - Solidification · Undercooling $\cdot$ Copper alloys

\section{Introduction}

In line with investigations on the effect of solute additions on the grain size in copper, growth restriction factors $(\mathrm{Q})$ have been determined as exemplified by means of the conventional (Eq. 1) [4-7] or true (Eq. 2) [2, 8, 9] Q values to quantify the potential restriction to growth imposed by a solute. The conventional $\mathrm{Q}$ was expanded to multicomponent systems but disregarding solute-solute interactions, in which the true $\mathrm{Q}$ accounts for [8].

M. J. Balart

maria.balart@brunel.ac.uk

F. Gao

feng.gao@brunel.ac.uk

J. B. Patel

jayesh.patel@brunel.ac.uk

F. Miani

fabio.miani@uniud.it

1 BCAST, Brunel University London, Uxbridge, Middlesex UB8 3PH, UK

2 University of Udine, Via delle Scienze 208, 33100 Udine, Italy
$\mathrm{Q}_{\text {conv. }}=m C_{O}(k-1)$

where $m$ is the slope of the liquidus, $C_{O}$ is the solute concentration, and $k$ is the equilibrium distribution coefficient. Equation 1 captures the phase diagram of the alloy system. Therefore, the accuracy of the conventional $\mathrm{Q}$ depends not only on solute-solute interactions, but also on the resolution of the binary phase diagram [8] and the values of $k$ and $m$, which are not expected to be constant as they can vary with alloy composition and temperature $[8,10]$.

$\mathrm{Q}_{\text {true }}=\left(\frac{\partial\left(\Delta T_{\mathrm{cs}}\right)}{\partial f_{s}}\right)_{f_{s} \rightarrow 0}$

where $\Delta T_{\mathrm{cs}}$ is the constitutional undercooling and $f_{s}$ is the solid fraction.

$\Delta T_{\mathrm{cs}}=T_{L}-T$

where $T_{L}$ is the liquidus temperature

$\mathrm{Q}_{\text {true }}$ was thermodynamically-calculated for each amount of solute present in binary copper alloys by relating $\Delta T_{\mathrm{cs}}$ to the solid fraction $\left(f_{s}\right)$ as described by Cziegler and Schumacher [8]: 
$\Delta T_{c s}=a+b f_{s}+c f_{s}^{2}$

and linking to the $\mathrm{Q}_{\text {true }}$ Eq. (2) as derived by Schmid-Fetzer and Kozlov [2]. It follows that the derivative of second-order polynomial at $f_{s} \rightarrow 0$ (Eq. 4), leads to $\mathrm{Q}_{\text {true }}=b$

Another parameter proposed for evaluating the effect of solute additions on grain refinement, for example in $\mathrm{Al}$ alloys, has been the constitutional supercooling parameter (P) [9]. Its accuracy is also dependent on the accuracy of $k$ and $m$ values.

$P=\frac{m C_{O}(k-1)}{k}$

Men and Fan [11] have highlighted, based on previously reported experimental results, that a simple linear relationship between grain size and growth restriction factor cannot hold in some cases. In their work [11], they developed theoretically and proved empirically a correlation between grain size and the reciprocal of the conventional growth restriction factor to be a power of law of $1 / 3$. This was subsequently adapted to the true growth restriction factor on a study of the effects of superheat and solute additions of $\mathrm{Al}, \mathrm{Zn}, \mathrm{P}, \mathrm{Mg}, \mathrm{Mn}, \mathrm{Ni}, \mathrm{Pb}$, and $\mathrm{Sn}$ on the grain size at a constant degree of superheat in binary copper alloys [12]. This paper extends our previous study to other binary copper alloys.

More recently, Fan et al. [3] defined the new growth restriction parameter $(\beta)$ :

$\beta=\frac{m C_{O}(k-1)}{\Delta T}-k=\frac{\mathrm{Q}_{\text {conv. }}}{\Delta T}-k$

where $\Delta T$ is a fixed undercooling during solidification.

It is of interest to note that by replacing $\Delta T=m\left(C_{O}-\right.$ $C_{L}$ ) and $k=C_{S} / C_{L}$ into Eq. 6, Fan et al. [3] obtained the heuristic solution for the accurate calculation of $\beta$ values for a binary system (Eq. 7), which extended to multicomponent systems by the linear addition of each binary system $\beta_{\mathrm{i}}$ (Eq. 8) assuming no interactions between solutes.

$\beta=\frac{C_{O}-C_{S}}{C_{L}-C_{O}}=\frac{f_{L}}{f_{S}}$

$\beta=\sum_{i=1}^{n} \beta_{i}$

For eutectic systems, $k<1$, then the difference between $\beta$ calculated from Eq. 6 and that calculated from Eq. 7 is small and Eq. 6 is a good estimate of values of $\beta$. However, for peritectic systems, $k>1$, such difference is larger and the calculation of $\beta$ from the ratio of liquid to solid fraction (Eq. 7) is more accurate [3].
It was also derived in Ref. [3], the growth restriction coefficient $\left(2 / \lambda^{2}\right.$, (Eq. 9)), which applies for spherical growth during solidification.

$\frac{2}{\lambda^{2}}=\frac{1-\alpha}{\alpha(1+\sqrt{\alpha}+\alpha)}$

As well as the relationship between $\beta$ and the solute supersaturation $(\alpha)$

$\alpha=\frac{1}{\beta+1}$

Critical solute concentrations are calculated by Eq. 11, which was obtained by rearranging Eq. 6 at $\beta=0$.

$C^{*}=\frac{k \Delta T}{m(k-1)}$

Physically, $C^{*}$ is the critical solute concentration for the onset of growth restriction [3], i.e., for a given undercooling:

if $C_{O}<C^{*}$, there is no growth restriction,

if $C_{O}>C^{*}$, there is growth restriction, the degree of which increased with increasing solute concentration.

We also update the earlier calculations [5] to take into account the heuristic $\beta$.

Previous studies have shown a low correlation between $\mathrm{Q}_{\text {conv. }}$ [4-6] and $\mathrm{Q}_{\text {true }}$ [8] values and grain size in binary $\mathrm{Cu}$ alloys. Plots of the variation of grain size values with $\mathrm{Q}_{\text {conv. }}$ were reported for many binary $\mathrm{Cu}$ alloys in the former studies [4-6], however, only for $\mathrm{P}, \mathrm{Zr}$, and $\mathrm{Ni}$ in the latter study [8]. Here, we report columnar grain length values from Northcott's work [1] for binary $\mathrm{Cu}$ alloys plotted against the undercooling parameter $(\mathrm{P})$, the reciprocal of the conventional growth restriction factor $\left(\mathrm{Q}_{\text {conv. }}\right)$ values and the reciprocal of the true growth restriction factor $\left(\mathrm{Q}_{\text {true }}\right)$ [2] values for different solutes and cast at different degrees of superheat. Furthermore, the heuristic growth restriction parameter $(\beta)$ [3] modeling framework in conjunction with the critical solute content $\left(C^{*}\right)$ for growth restriction has also been applied to binary $\mathrm{Cu}$ alloys. This work has been undertaken to compare and contrast the three different factors, namely $\mathrm{P}, \mathrm{Q}_{\text {conv. }}$ and $\mathrm{Q}_{\text {true }}$ and the holistic parameter $\beta$ in conjunction with the critical solute content $\left(C^{*}\right)$ for growth restriction in predicting the grain size in binary copper alloys. A priori, $\beta$ is expected to give a better fit than that of others.

\section{True Growth Restriction Factor Q}

The true growth restriction factor $\mathrm{Q}$ was thermodynamically-calculated for each amount of solute present in binary copper alloys using the methodology described by Cziegler and Schumacher [8] based on the original Schmid-Fetzer 


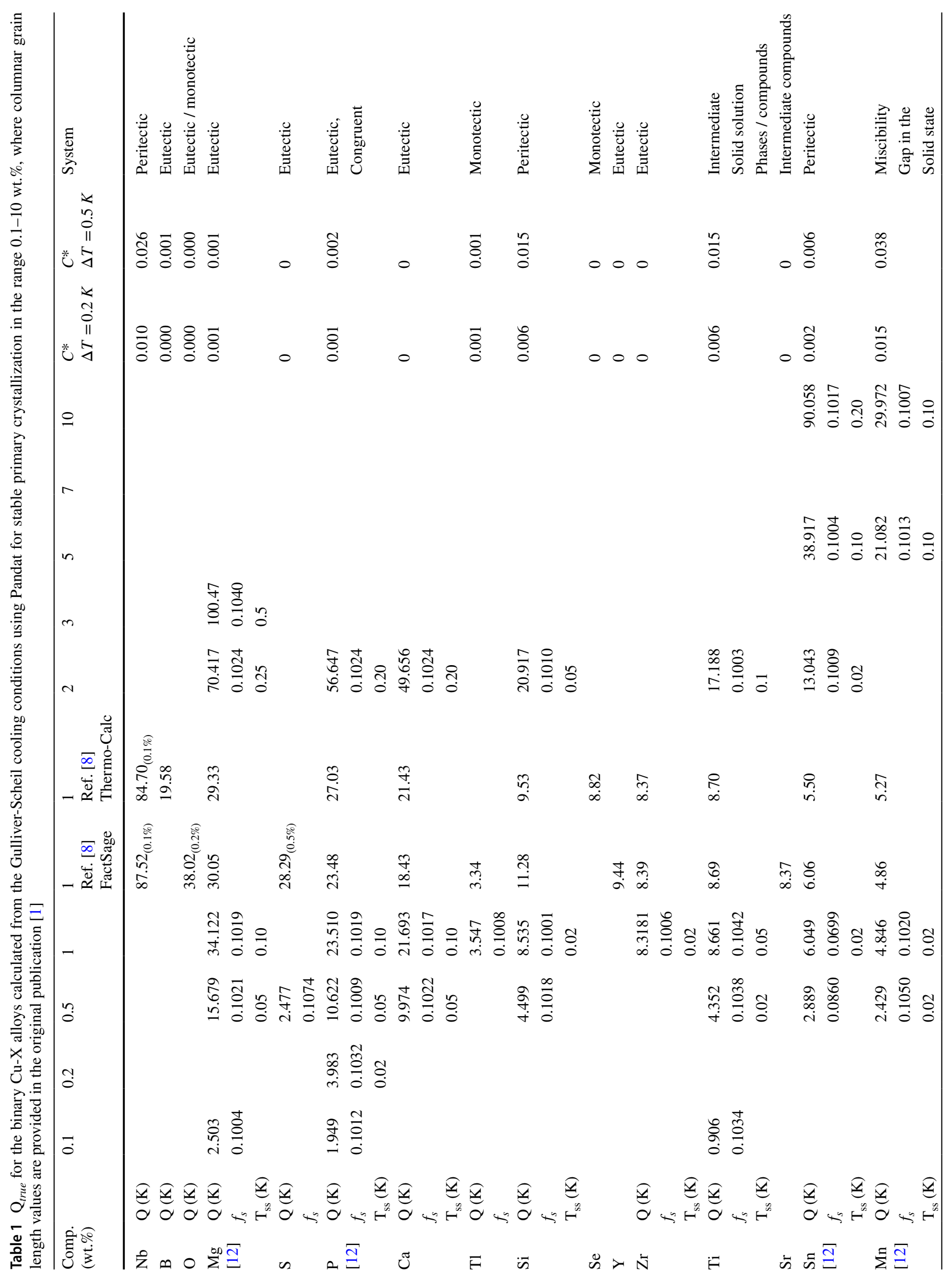




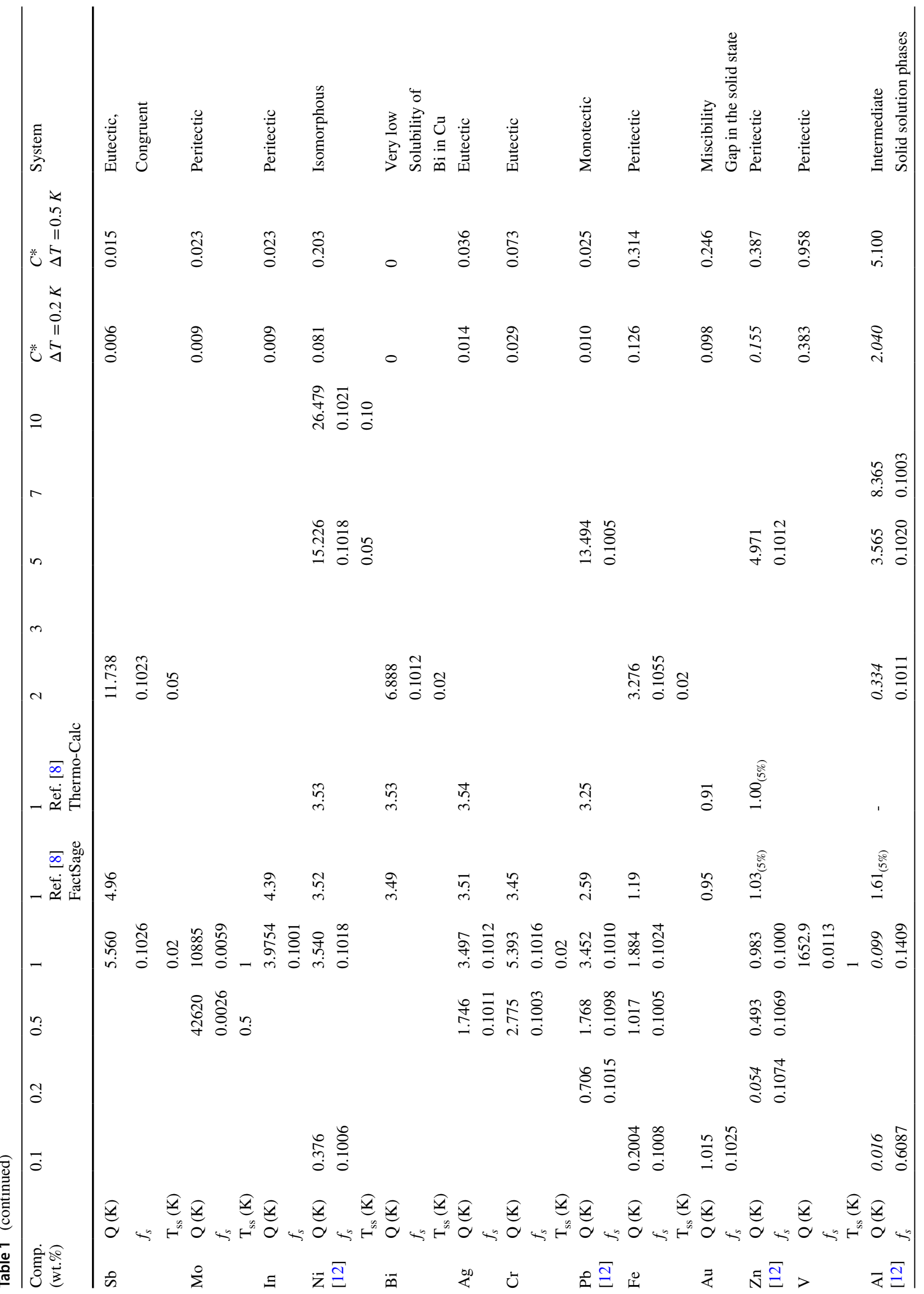




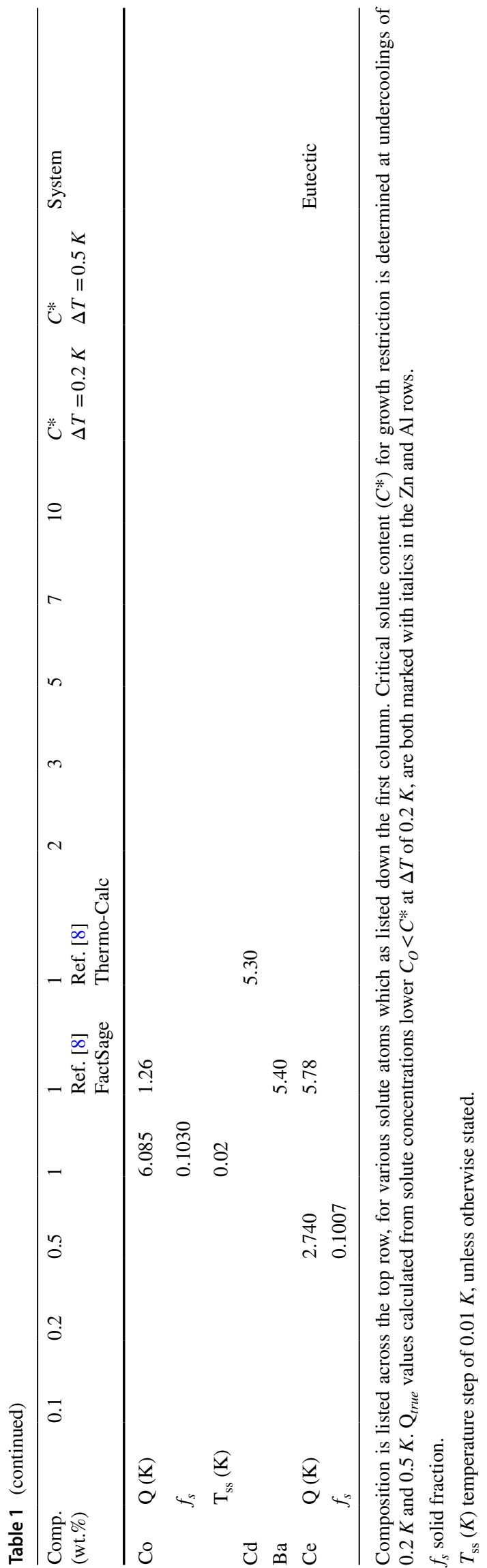

and Kozlov's work [2]. This procedure was briefly described in our previous work [12]. Cooling was calculated from the thermodynamic databases available in the literature using Software package Pandat (version 8.0) following a compilation of Refs. [13-19] as cited in our previous work [12] and an extension to other binary copper alloys [20-40]. The solid fraction evolution within a relatively small fraction $\left(f_{s}\right)$ as detailed in Table 1 was calculated based on the GulliverScheil cooling conditions generally for a temperature step of $0.01 \mathrm{~K}$, except where otherwise stated in Table 1 .

\section{Growth Restriction Parameter $\beta$}

Values of $m$ and $k$ were calculated and reported in Ref. [5] from which $\mathrm{Q}_{\text {conv. }}$ values were determined in the present investigation. $\beta$ defined from Eq. 6 was evaluated at a constant $\Delta T$ value of $0.2 \mathrm{~K} . \alpha$ was calculated from the relationship with $\beta$ (Eq. 10) obtained by Fan et al. [3] for calculating subsequently values of $2 / \lambda^{2}$ using Eq. 9 .

\section{Results and Discussion}

$\mathrm{Q}_{\text {true }}$ values calculated at a solute content of $1 \mathrm{wt} . \%$ of Ref. [8] and those calculated at different solute concentrations are compared in Table 1. In the latter case, columnar grain length values of Ref. [1], are plotted against the $P$, reciprocal of the $\mathrm{Q}_{\text {conv. }}$ and $\mathrm{Q}_{\text {true }}$ values for different solutes and degrees of superheat in Fig. 1. Note that, columnar grain length values of Ref. [1] were assessed for additions into copper rapidly cast in air ( $\sim 3.175 \mathrm{~kg}$ ingot castings, $76.2 \mathrm{~mm}$ diameter and $\sim 76.2 \mathrm{~mm}$ height). Unrestricted type of columnar grain growth can occur under high thermal gradient (from liquid to solid).

Despite of the fact that a direct relationship between the columnar grain size and the reciprocal of the true growth restriction factor at a constant degree of superheat was found to be of a power of law of $1 / 3$ for individual solute additions of $\mathrm{P}, \mathrm{Mg}, \mathrm{Mn}, \mathrm{Pb}$, and $\mathrm{Sn}$ [12], which were also included in Fig. 1; there was no correlation between columnar grain length values from Northcott's work [1] and the $\mathrm{P}, 1 / \mathrm{Q}_{\text {conv. }}$. and $1 / Q_{\text {true }}$ values for different solutes and cast at the same degree of superheat. This is because it is expected that simi$\operatorname{lar} \mathrm{P}, 1 / \mathrm{Q}_{\text {conv. }}$, and $1 / \mathrm{Q}_{\text {true }}$ values would give similar grain size values under the same casting conditions, independently of the alloy system. Relatively higher P and lower both $1 /$ $\mathrm{Q}_{\text {conv. }}$ and $1 / \mathrm{Q}_{\text {true }}$ values would be expected to correlate highly with finer grain sizes. This is however not the case in Fig. 1. In the work from which Eq. (2) was derived [2], it has been highlighted that $\mathrm{Q}_{\text {true }}$ is identical to $\mathrm{Q}_{\text {conv. }}$ in the limit $f_{s} \rightarrow 0$. 
A

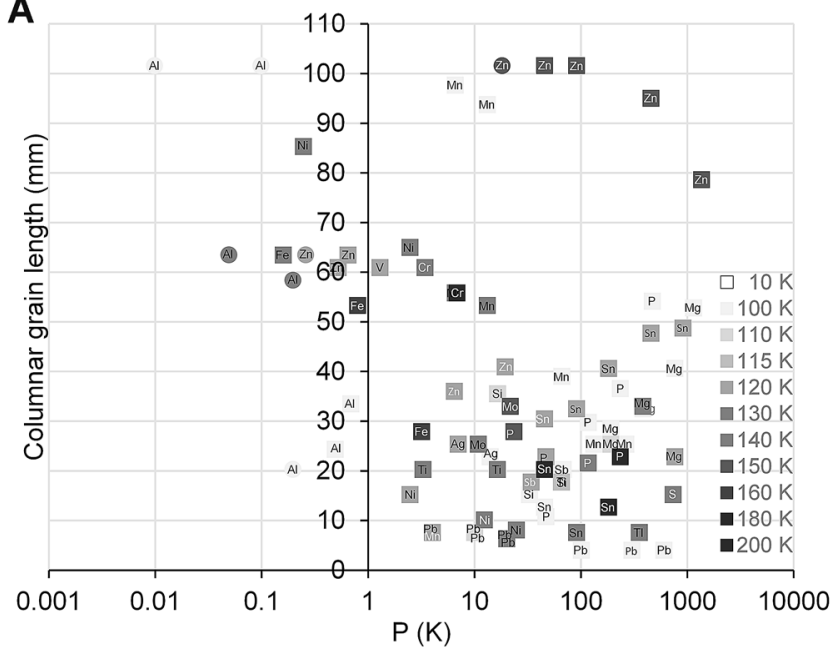

B

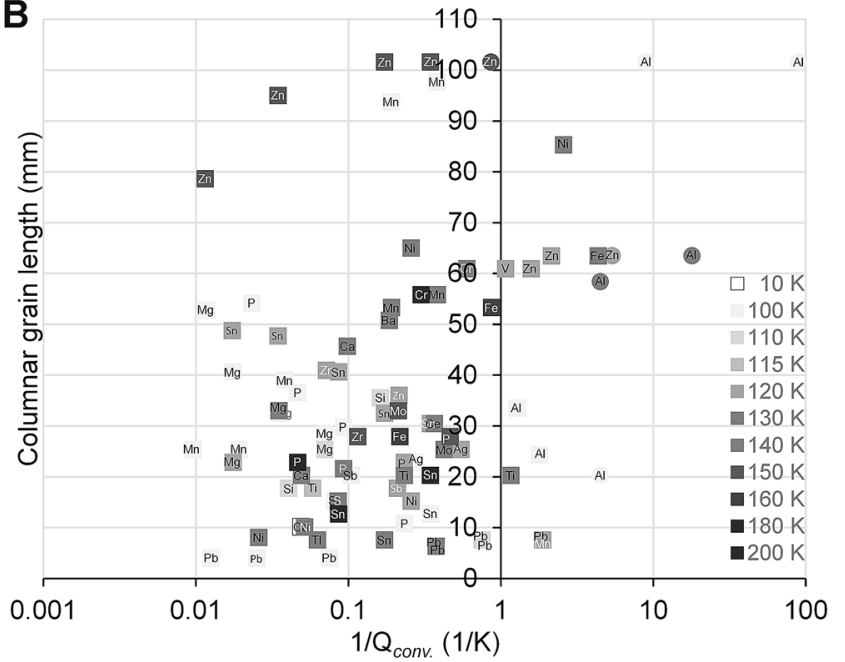

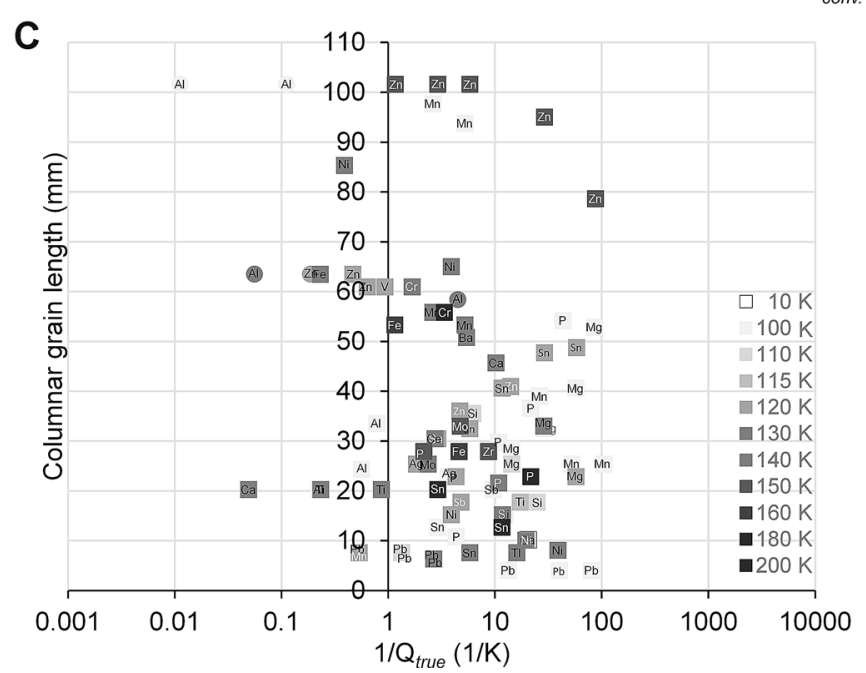

Fig 1 Variation of columnar grain length values of Ref. [1] with (a) $\mathrm{P}$, and the reciprocal of (b) $\mathrm{Q}_{\text {conv. }}$ and (c) $\mathrm{Q}_{\text {true }}$ values for different solutes and degrees of superheat.

Values of $C^{*}$ at $\Delta T$ of $0.2 \mathrm{~K}$ and $0.5 \mathrm{~K}$ are given in Table 1. $\mathrm{Q}_{\text {true }}$ values calculated from solute concentrations lower $C_{O}<C^{*}$ at $\Delta T$ of $0.2 \mathrm{~K}$, are both marked with italics in the $\mathrm{Zn}$ and $\mathrm{Al}$ rows in Table 1 and with circle symbols in Fig. 1. Interestingly, those points generally correspond to $\mathrm{Zn}$ and $\mathrm{Al}$ lying on the top, right hand side corner of the graph, where coarse columnar grains are represented, except for an $\mathrm{Al}$ point and a $\mathrm{Zn}$ point, in which case and as mentioned in Ref. [12] due to its inherent high equilibrium vapor pressure, these $\mathrm{Cu}-\mathrm{Zn}$ alloys could have had a lower $\mathrm{Zn}$ content in the base composition than its corresponding nominal composition, which in turn may have resulted in an overestimation of the $\mathrm{Q}_{\text {true }}$ values.

Next, from the viewpoint of the new growth restriction modeling framework [3], $2 / \lambda^{2}$ values are correspondingly represented against the ratio of $\mathrm{Q}_{\text {conv. }}$ to $\Delta T$ in Fig. 2 and $\beta$ values in Fig. 3. Note that, from Fig. 2, the intercept at the
$\mathrm{Q}_{\text {conv. }} / \Delta T$ corresponds to $\mathrm{k}$ as highlighted in the work from which Eq. 6 was derived by Fan et al. [3]. Finally, from Fig. 3, a direct relationship between $2 / \lambda^{2}$ and $\beta$ values has been found in this work in binary copper alloys, in agreement with results originally reported by Fan et al. [3].

\section{Conclusions}

The undercooling parameter, $\mathrm{P}$, conventional $\mathrm{Q}_{\text {conv. }}$ and true $\mathrm{Q}_{\text {true }}$ growth restriction factors as well as the heuristic growth restriction parameter $(\beta)$ modeling frameworks have been applied to binary $\mathrm{Cu}$ alloys. There was no correlation between columnar grain length values from Northcott's work [1] and the $\mathrm{P}$, reciprocal of the $\mathrm{Q}_{\text {conv. }}$ and $\mathrm{Q}_{\text {true }}$ values for different solutes and cast at the same degree of superheat. Unlike $\mathrm{P}, \mathrm{Q}_{\text {conv. }}$, and $\mathrm{Q}_{\text {true }}$ values, the heuristic 

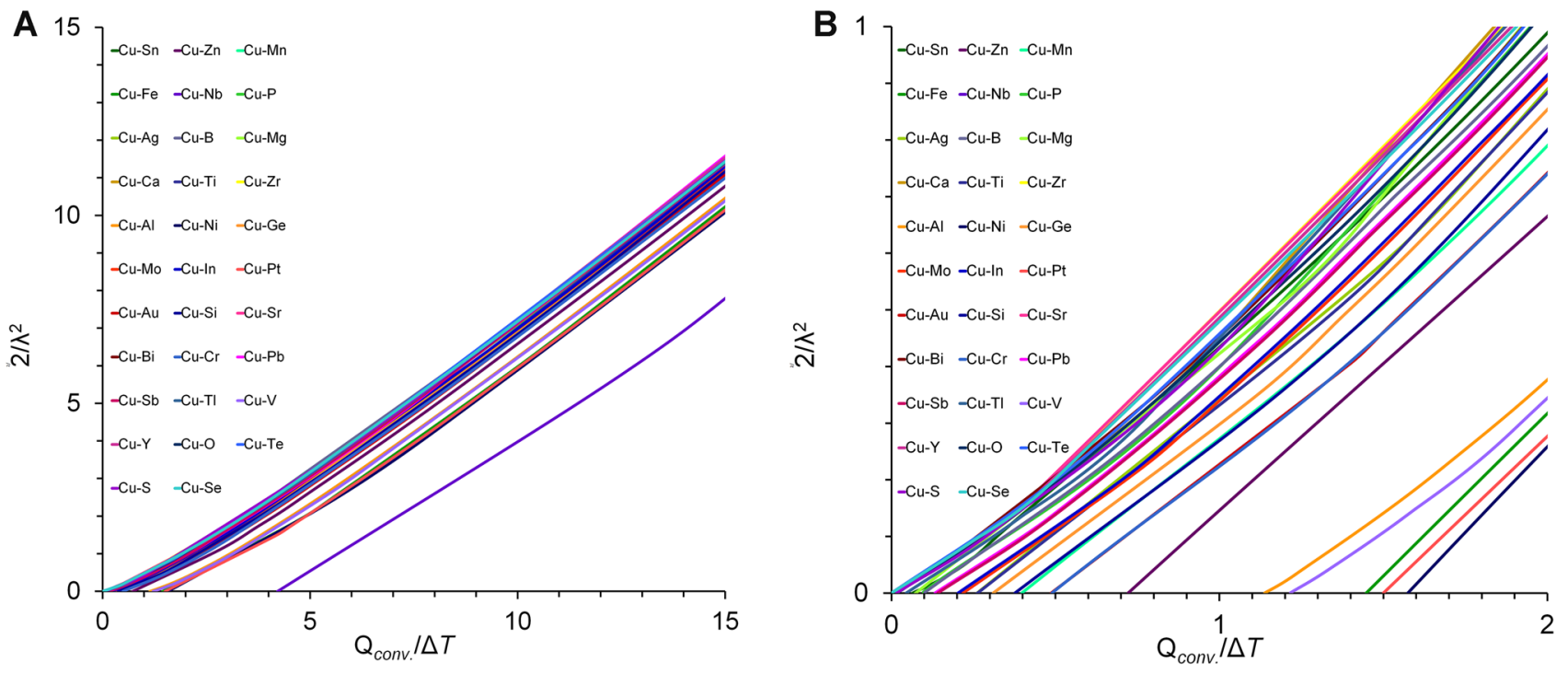

Fig 2 (a) Variation of $2 / \lambda^{2}$ values with the ratio of $\mathrm{Q}_{\text {conv. }}$ to $\Delta T$ at $\Delta T=0.2 \mathrm{~K}$ for binary copper alloys and (b) detailed region.

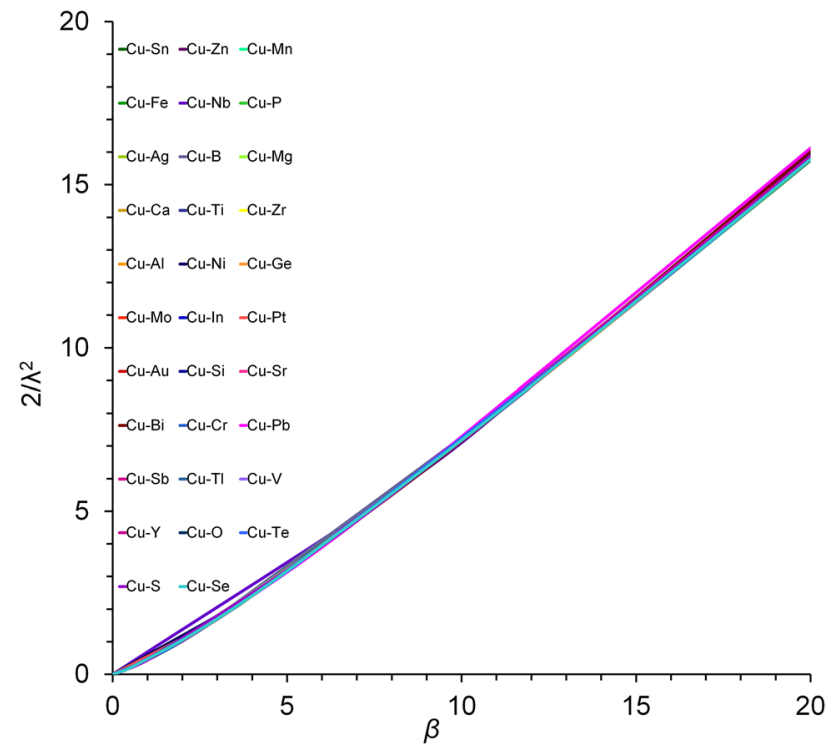

Fig 3 Variation of $2 / \lambda^{2}$ values with $\beta$ at $\Delta T=0.2 \mathrm{~K}$ for binary copper alloys.

growth restriction parameter $(\beta)$ [3] modeling framework in conjunction with the critical solute content $\left(C^{*}\right)$ for growth restriction fitted well to binary $\mathrm{Cu}$ alloys. Based on the latter analysis, a direct relationship between the growth restriction coefficient $\left(2 / \lambda^{2}\right)$ and the heuristic growth restriction parameter $(\beta)$ was found in this work in dilute binary copper alloys. As concluded in Ref. [3], this means that growth velocity is a unique function of the growth restriction parameter $(\beta)$, which is dependent on the nature of solutes, solute concentrations and solidification conditions. However, growth velocity is not a unique function of $\mathrm{P}, \mathrm{Q}_{\text {conv }}$, and $\mathrm{Q}_{\text {true }}$ values.

Acknowledgement The support of the EPSRC (UK) is gratefully acknowledged.

Open Access This article is licensed under a Creative Commons Attribution 4.0 International License, which permits use, sharing, adaptation, distribution and reproduction in any medium or format, as long as you give appropriate credit to the original author(s) and the source, provide a link to the Creative Commons licence, and indicate if changes were made. The images or other third party material in this article are included in the article's Creative Commons licence, unless indicated otherwise in a credit line to the material. If material is not included in the article's Creative Commons licence and your intended use is not permitted by statutory regulation or exceeds the permitted use, you will need to obtain permission directly from the copyright holder. To view a copy of this licence, visit http://creativecommons.org/licenses/by/4.0/.

\section{References}

1. L. Northcott, The influence of alloying elements on the crystallization of copper. Part I.- - small additions and the effect of atomic structure. J. Inst. Metals 62, 101-136 (1938)

2. R. Schmid-Fetzer, A. Kozlov, Thermodynamic aspects of grain growth restriction in multicomponenet alloy solidification. Acta Mater. 59(15), 6133-6144 (2011)

3. Z. Fan, F. Gao, L. Zhou, S.Z. Lu, A new concept for growth restriction during solidification. Acta Mater. 152, 248-257 (2018)

4. A.K. Cziegler, P. Schumacher, Preliminary investigation of the grain refinement mechanism in $\mathrm{Cu}$ alloys. In: M. Tiryakioglu, M. Jolly, G. Byczynski (Eds.). Proceedings of the 6th Shape Cast Int Symp TMS; Nashville, TN: John Wiley \& Sons, Inc; 2016 Feb 14-18. p.p. 159-166 
5. M.J. Balart, J.B. Patel, F. Gao, Z. Fan, Grain refinement of deoxidized copper. Metall. Mater. Trans. A. 47A(10), 4988-5011 (2016)

6. A. Cziegler, O. Geraseva, P. Schumacher, Numerical and experimental investigation of the influence of growth restriction on grain size in binary $\mathrm{Cu}$ alloys. Metals 7, 383 (2017)

7. Z. Liu, Review of grain refinement of cast metals through inoculation: theories and developments. Met. Mater. Trans. A 48A, 4755-4776 (2017)

8. A.K. Cziegler, P. Schumacher, Investigation of the correlation between growth restriction and grain size in $\mathrm{Cu}$ alloys. Int. J. Cast Met. Res. 30(4), 251-255 (2017)

9. L.A. Tarshis, J.L. Walker, J.W. Rutter, Experiments on the solidification structure of alloy castings. Metall. Trans. 2, 2589-2597 (1971)

10. H. Xu, L.D. Xu, S.J. Zhang, Q. Han, Effect of the alloy composition on the grain refinement of aluminum alloys. Scripta Mater. 54, 2191-2196 (2006)

11. H. Men, Z. Fan, Effect of solute content on grain refinement in an isothermal melt. Acta Mater. 59, 2704-2712 (2011)

12. M.J. Balart, F. Gao, J.B. Patel, F. Miani, Effects of superheat and solute additions on the grain size in binary copper alloys. Metallography Microstruct. Anal. 8(4), 566-572 (2019)

13. J. Miettinen, Thermodynamic description of $\mathrm{Cu}-\mathrm{Sn}-\mathrm{P}$ system in the copper-rich corner. Calphad 25(1), 67-78 (2001)

14. X.J. Liu, C.P. Wang, I. Ohnuma, R. Kainuma, K. Ishida, Experimental investigation and thermodynamic calculation of the phase equilibria in the $\mathrm{Cu}-\mathrm{Sn}$ and $\mathrm{Cu}-\mathrm{Sn}-\mathrm{Mn}$ systems. Metall. Mater. Trans. A 35(6), 1641-1654 (2004)

15. M. Jiang, C.P. Wang, X.J. Liu, I. Ohnuma, R. Kainuma, G.P. Vassilev, K. Ishida, Thermodynamic calculation of phase equilibria in the $\mathrm{Cu}-\mathrm{Ni}-\mathrm{Zn}$ system. J. Phys. Chem. Solids 66(2-4), 246-250 (2005)

16. J. Miettinen, Thermodynamic description of the $\mathrm{Cu}-\mathrm{Al}-\mathrm{Sn}$ system in the copper-rich corner. Metall. Mater. Trans. A 33A(6), 1639-1648 (2002)

17. J.J.P. Vřešt'álŠtěpánkováBrož, Thermodynamics of the coppermanganese system Knudsen-cell mass spectrometric study of the liquid $\mathrm{Cu}-\mathrm{Mn}$ system and calculation of the phase diagram. Scand J Metall. 25(5), 224-231 (1996)

18. T. Buhler, S.G. Fries, P.J. Spencer, H.L. Lukas, A thermodynamic assessment of the Al-Cu-Mg ternary system. J. Phase Equilib. 19(4), 317-333 (1998)

19. C.P. Wang, X.J. Liu, I. Ohnuma, R. Kainuma, K. Ishida, Thermodynamic assessment of the $\mathrm{Cu}-\mathrm{Ni}-\mathrm{Pb}$ system. Calphad 24(2), 149-167 (2000)

20. D. Risold, B. Hallstedt, L.J. Gauckler, H.L. Lukas, S.G. Fries, Thermodynamic optimization of the $\mathrm{Ca}-\mathrm{Cu}$ and $\mathrm{Sr}-\mathrm{Cu}$ systems. Calphad 20(2), 151-160 (1996)

21. X.C. He, H. Wang, H.S. Liu, Z.P. Jin, Thermodynamic description of the $\mathrm{Cu}-\mathrm{Ag}-\mathrm{Zr}$ system. Calphad 30(4), 367-374 (2006)

22. W. Gierlotka, K.C. Zhang, Y.P. Chang, Thermodynamic description of the binary $\mathrm{Cu}-\mathrm{Zr}$ system. J. Alloys Compd. 509(33), 8313-8318 (2011)

23. R. Arroyave, T.W. Eagar, L. Kaufman, Thermodynamic assessment of the $\mathrm{Cu}-\mathrm{Ti}-\mathrm{Zr}$ system. J. Alloys Compd. 351(1-2), 158$170(2003)$
24. M.A. Turchanin, P.G. Agraval, A.R. Abdulov, Thermodynamic assessment of the $\mathrm{Cu}-\mathrm{Ti}-\mathrm{Zr}$ system. I Cu-Ti system. Powder Metall. Met. Ceram. 47, 344-360 (2008)

25. X.J. Liu, H.S. Liu, I. Ohnuma, R. Kainuma, K. Ishida, S. Itabashi, K. Kameda, K. Yamaguchi, Experimental determination and thermodynamic calculation of the phase equilibria in the $\mathrm{Cu}-\mathrm{In}-\mathrm{Sn}$ system. J. Electron. Mater. 30(9), 1093-1103 (2001)

26. H.S. Liu, Y. Cui, K. Ishida, X.J. Liu, C.P. Wang, I. Ohnuma, R. Kainuma, Z.P. Jin, Thermodynamic assessment of the $\mathrm{Cu}-\mathrm{In}$ binary system. J. Phase Equilib. 23(5), 409-415 (2002)

27. C.P. Wang, X.J. Liu, I. Ohnuma, R. Kainuma, K. Ishida, S.M. $\mathrm{Hao}$, Phase Equilibria in the $\mathrm{Cu}-\mathrm{Fe}-\mathrm{Mo}$ and $\mathrm{Cu}-\mathrm{Fe}-\mathrm{Nb}$ Systems. J. Phase Equilib. 21(1), 54-62 (2000)

28. Q. Chen, Z. Jin, The Fe-Cu system: A thermodynamic evaluation. Metall. Mater. Trans. A 26(2), 417-426 (1995)

29. D. Lüdecke, A thermodynamic assessment of the $\mathrm{Cu}-\mathrm{Si}$ system. Calphad 11(2), 135-142 (1987)

30. X. Yan, Y.A. Chang, A thermodynamic analysis of the $\mathrm{Cu}-\mathrm{Si}$ system. J. Alloys Compd. 308(1-2), 221-229 (2000)

31. M. Hämäläinen, K. Jääskeläinen, R. Luoma, M. Nuotio, P. Taskinen, O. Teppo, A thermodynamic analysis of the binary alloy systems $\mathrm{Cu}-\mathrm{Cr} \mathrm{Cu}-\mathrm{Nb}$ and $\mathrm{Cu}-\mathrm{V}$. Calphad 14(2), 125-137 (1990)

32 K.G.S.P.J. ItagakiQianMeySpencer, Evaluation of the phase diagram and thermochemistry of the CU-Y system. Calphad 14(4), 377-384 (1990)

33. L. Schramm, G. Behr, W. Löser, K. Wetzig, Thermodynamic reassessment of the $\mathrm{Cu}-\mathrm{O}$ phase diagram. J. Phase Equilib. Diffusion 26(6), 605-612 (2005)

34. C. Guo, X. Zhang, C. Li, Z. Du, Thermodynamic description of the $\mathrm{Cu}-\mathrm{S}-\mathrm{Sn}$ system. Int. J. Mater. Res. 109(3), 201-218 (2018)

35. D.J. Chakrabarti, D.E. Laughlin, The $\mathrm{Cu}-\mathrm{Tl}$ (Copper-Thalium) system. Bull. Alloy Phase Diagrams 5(2), 156-160 (1984)

36. W. Gierlotka, D. Jendrzejczyk-Handzlik, Thermodynamic description of the $\mathrm{Cu}-\mathrm{Sb}$ binary system. J. Alloys Compd. 484(1-2), $172-176(2009)$

37. O. Akinlade, R.N. Singh, F. Sommer, Thermodynamic investigation of viscosity in $\mathrm{Cu}-\mathrm{Bi}$ and $\mathrm{Bi}-\mathrm{Zn}$ liquid alloys. J. Alloys Compd. 267(1-2), 195-198 (1998)

38. B. Sundman, S.G. Fries, W.A. Oates, A thermodynamic assessment of the Au-Cu system. Calphad 22(3), 335-354 (1998)

39. M. Palumbo, S. Curiotto, L. Battezzati, Thermodynamic analysis of the stable and metastable $\mathrm{Co}-\mathrm{Cu}$ and $\mathrm{Co}-\mathrm{Cu}-\mathrm{Fe}$ phase diagrams. Calphad 30(2), 171-178 (2006)

40. H. Bo, S. Jin, L.G. Zhang, X.M. Chen, H.M. Chen, L.B. Liu, F. Zheng, Z.P. Jin, Thermodynamic assessment of Al-Ce-Cu system. J. Alloys Compounds. 484(1-2), 286-295 (2009)

Publisher's Note Springer Nature remains neutral with regard to jurisdictional claims in published maps and institutional affiliations. 